\title{
POULTRY - AN UPRISING AND SMART GROWING FIELD IDEAL FOR RURAL: AN OVERVIEW
}

\author{
M.Krishnamoorthy \\ PG \& Research Department of Zoology \\ The American College, Madurai, Tamilnadu, India
}

\begin{abstract}
Poultry - is the one of the famous and fastgrowing unit in India and worldwide. It begins its journey as a small-scale industry and now it growing as a huge sector, make the economic impacts on our country as well as in other countries also. It meets all the requirements for the cheap protein source and it is easily available for everyone. It is the suitable industry sector for both large scale bulk production and small-scale backyard production. In India, the need for poultry is enormously increasing day by day. Poultry farming also impact the exports and import values of our country's economy. This review article is designed to overview the poultry farming aspects, poultry producing systems, Indian poultry sector, poultry products obtained through farming, SWOT analysis about poultry farming and finally it's scopes. This review is designed for farmers, Entrepreneurs, and academic scholars who are interested in poultry farming and related studies.
\end{abstract}

Keywords: Poultry, Broiler, Layers, Indian economy, Chicken products

\section{INTRODUCTION}

RVO.nl (2017) reports that the poultry industry in India represents a major success story. backyard venture before the 1960s has been transformed into a vibrant agribusiness with an annual turnover of Rs 30000 crores today. Rajesh Mehta. et al reveals that in recent days, after china and the USA, India is the $3^{\text {rd }}$ largest egg producing country and the $4^{\text {th }}$ huge chicken manufacturing country in the world after china, brazil and the USA. Poultry sector in India worth in Euros up to 14,500 million. By years Production of broiler carcass has increased 4.2 million tons per year. Mandate for the processed chicken meat has been growing by $15-20 \%$ per annum. Total layer production in India has gone up to reach 80 million eggs per annum.RVO.nl also commented that uundoubtedly, this remarkable growth is a result of several factors, such as active developmental support from the state and central governments, applied research and development support from research institutes. Justyna batkowska et.al(2017) studied and reveals that by intensive rearing system, most of the poultry products are obtained in India. the production of poultry meat is based on fast growing birds. their carcasses are characterized by:

\author{
P.Velladurai \\ PG \& Research Department of Zoology \\ The American College, Madurai, Tamilnadu, India
}

maximum portions of muscles, minimum proportion of bone and optimum proportion of fat dictated by specific trade preferences. From the views of Grashorn (2007), In future, the poultry products such as meat and egg, will be included in the category of functional foods. Latshaw et.al stated in their research was poultry products are nutritious and add variety to the human diet. Most of the products are from the chickens, but ducks and turkeys also are important sources. In developing countries, rural production systems for maintaining poultry are not far removed from conditions encountered by wild chickens and ducks. Poultry field has very long evolutionary origin and it crossed many countries and periodic ages.

\section{A. POULTRY PRODUCING SYSTEMS}

According to the reports of Colin Scanes (2007), Poultry are produced across the world by 3 major systems:

Profitable large-scale poultry production systems;

Traditional village scavenging poultry (largely in developing countries); this is similar to "backyard" or "farmyard" poultry in Europe.

Semi-profitable systems (close to urban areas in developing countries)

In addition, there are alternative systems, including free range and organic.

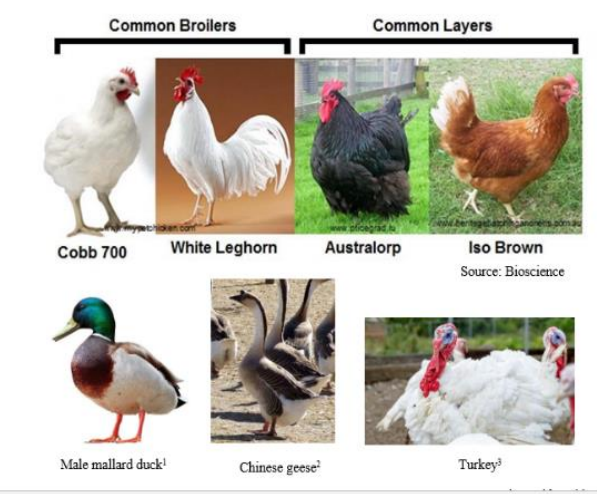

Fig. 1. Various Poultry breeds 


\section{International Journal of Engineering Applied Sciences and Technology, 2020 \\ Vol. 5, Issue 5, ISSN No. 2455-2143, Pages 261-264 \\ Published Online September 2020 in IJEAST (http://www.ijeast.com)}

\section{B. TYPES OF CHICKENAND THEIR ROLE IN POULTRY}

In case of poultry sector, two types of chicken are grown respectively layers and broilers. The layers are the prime source of eggs, whereas the broilers are grown for meat and carcass. Comparatively, both layers and broilers require same type of management needs. The proportion of growth and economy of poultry industry depends fully on the variety of breeds and the management activities. Nowadays there are wide variety of high egg laying layers and broilers are available I commercial market. These range of varieties are produced by hybridization process. The young chicks of high quality breeds in both layers and broilers are reared and maintained by hatcheries. The initial stage of poultry farming is undoubtfully starts with these high quality chicks. These chicks are separated on very first day one-day and are to be subjected for brooding. Brooding is the sum of care and management activities exerted in the first few weeks after hatching (40 to 60 days).for the large scale obtaining, nowadays artificial breeding techniques are employed in this sector. artificial breeding is the method of supervision and management of young chicks without the help of maternal hen. In this process, the rearing houses and cages should be customised for the baby chicks. By using insecticides and pesticides, the rearing houses and the handing equipment should be kept clean. The final body weight of the broilers is mainly based on Feed conversion ratio (FCR).

\section{POULTRY IN INDIA}

The poultry sector $\mathrm{n}$ India has experienced a significant change in structure and operation in the recent two decades changing from the mere courtyard activity to a significant viable activity with the presence of big good players with effective execution of poultry, cultivating on a vast scale. India is the second largest egg and third largest in broiler - chicken producer in the world. The Indian poultry market is largely concentrated in southern parts, Andrapradesh, Tamilnadu, and Telangana. Poultry sector in India is valued at about Rs. 80,000 crores broadly divided into two sub-sectors -one with highly organized commercial sector with about $80 \%$ of the total market share and other being unorganized with about $20 \%$ of the total market (backyard poultry). In India, 71 percent of Indians over the age of 15 are non-vegetarian. According to the McKinsey and company, the per capita chicken consumption is set to grow from 3.2 to $9.1 \mathrm{~kg}$ by 2030 , on account of rapidly changing consumption behavior of individuals, share of poultry\& other meat in household food consumption is expected to grow from $12 \%$ to $24 \%$ by 2030[8].

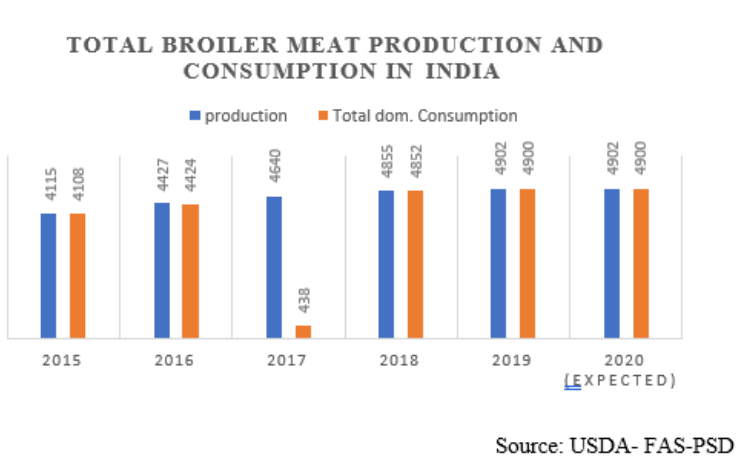

Fig. 2. Total broiler meat production

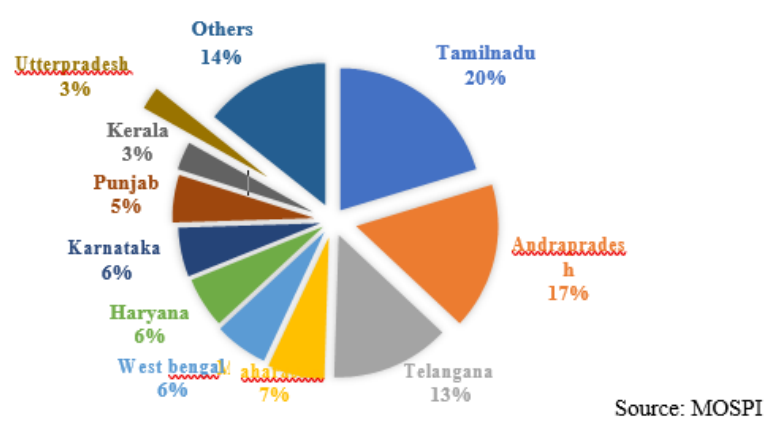

Fig. 3. Major Indian egg producing states

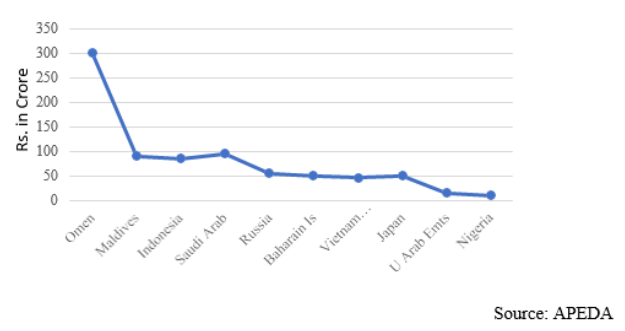

Fig. 4. Top 10 Poultry products importing countries from India

\section{Poultry Products}

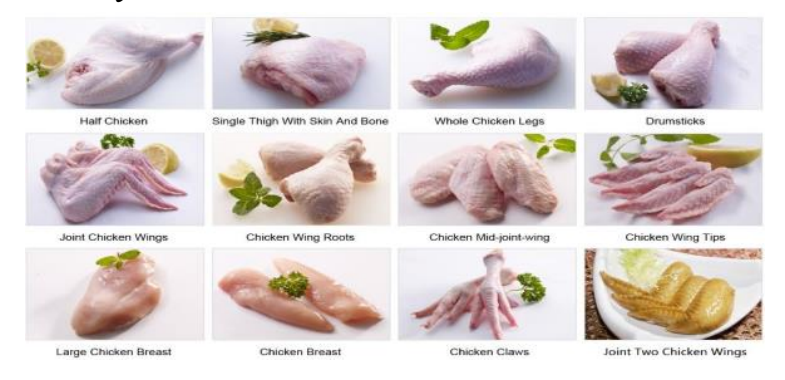




\section{International Journal of Engineering Applied Sciences and Technology, 2020 \\ Vol. 5, Issue 5, ISSN No. 2455-2143, Pages 261-264 \\ Published Online September 2020 in IJEAST (http://www.ijeast.com)}

\section{E. SWOT ANALYSIS POULTRY SECTOR-BOTH FOR EGGS AND POULTRY}

\section{STRENGTHS}

1. Good protein source at low cost

2. Increasing growth ratio- CAGR is around $5 \%$ for eggs and $7 \%$ for poultry; The CAGR of GVA for last 5 years for egg $-13 \%$ and poultry is $15 \%$.

3. Total Livestock population contributes nearly $12 \%$ to rural household monthly Income; Poultry alone can contribute nearly half (5-6\%) of the same Coping up with captive production of other plants like Soyabean and Maize

4. Strengthening of rural integrated operations by poultry supply chain.

\section{WEAKNESS}

1. Drawbacks in making value addition such as Poultry products processing, storing, Cold storage, refrigerated vehicles.

2. The price fluctuation of poultry feeds (soy bean and maize) leading to availability issues at affordable prices.

3. Small and handy farms make compromises in single man monthly income and biosecurity.

4. Poor handling and cutting will leads to low formation of diseases and greatly influenced in buying desire of buyer.

\section{Opportunities}

1. Work on developing alternate breeds and LIT birds for upgraded family poultry

2. Untapped potential for the export \& value-added chicken products.

\section{Threats}

1. Avian influenza and other emerging/re-emerging diseases

2. Calamity

\section{F. SCOPE WITH VALUE ADDED PRODUCTS FROM POULTRY}

1. Complete egg powder, pickled and salted eggs, egg cutlet, egg roll, egg soufflé, egg strips, egg crepe and waffles, powder, albumen flakes/ rings, yolk natural yellow pigment from yolk, conalbumin, lecithin, and avidin from eggs are used in food and pharmaceutical industries respectively.

2. Lysozyme, di-calcium phosphate from shell membranes and shells, cured and smoked chicken products, chicken soup, meat spreads, chicken patties, intermediate moisture diced products with long shelf-life, breast fillet battered and breaded enrobed products, chicken chunkalona, chicken essence, nuggets, kababs, marinated breast fillet, hot-dogs, frankfurtersetc. are add the good impressions to non-vegetarian food industries.

3. Other than meat and eggs, other products such as, giblets, liver and extract, feather meal and other inedible parts are used in poultry feed manufacturing industries.

4. There is an increasing demand already present in the commercial markets for the disease-free eggs.

\section{CONCLUSION}

Chatterjee.et.al (2015) reported that the poultry production in India continuous to exhibit spectacular growth in spite of several changes encountered over the years from the above informations and data, poultry farming is easy start-up Programme and easy to maintain industry. There are lots of central and state government allotted funds also promotes the production of poultry farming. Except the introduction of hormones and steroids to chicken, this industry will meet the all need of economical and dietary values of farmers and entrepreneurs, of course, this industry will definitely make a huge impact in Indian economy and Exports and Imports. Chandrakumaramangalam et al (2012) also concluded that poultry farming is highly adaptable under various conditions. For example, it fits well in mixed farming system to provide continuous income to the farmers during their lean period and also helps to engage their family labor profitable throughout the year.

\section{ACKNOWLEDGEMENTS}

The authors extend their thanks to PG \& Research department of Zoology and administration of The American College for their efforts and support.

\section{REFERENCES}

[1] RVO,Nl.(2017) Poultry sector. Opportunities and Challenges in India

[2] Rajesh Mehta and R.G. Nambiar. The poultry industry in India

[3] Justyna batkowska.,Kamil Drabik., Antoni brodacki (2017).Quantity and quality of poultry products depending on birds' rearing system. Journal of animal science, biology and Bioeconomy. vol. XXXV (3). DOI: 10.24326/jasbb.2017.3.6 
[4] Grashorn M.A. (2007). Functionality of Poultry Meat.JAPR. 2007 poultry science association.Inc

[5] Latshaw.J.D., Musharaf. N.A. Poultry Products as food vol I. Agricultural sciences

[6] Colin Scanes. (2007). Contribution of poultry to quality of life and Economic development in the developing world. DOI: $10.3382 / p s .2007-86-11-2289$

[7] http://www.biozoomer.com/2011/02/poultry-layersbroilers.html

[8] Indian poultry market overview (2016). Indian Council of Food and Agriculture

[9] National action plan for Egg \& Poultry-2022. DAHDF. MA\&FW. GOI

[10] Livestock and Poultry: world Markets and Trade (2019) United States Department of Agriculture-/FAS

[11] http://www.chinabaodi.com/en/product/3.html

[12] Chatterjee.RN., Rajkumar,U. (2015). An overview of poultry production in India. Indian Journal Of Animal Health(2015). 54(2): 89-108

[13] Chandrakumarmangalam.S. Vetrivel. S.C.(2012). A study on Production and Marketing of Poultry Eggs in Tamilnadu-India(with reference to Namakkal district) 